\title{
Chapter 1 \\ The Berlin Group and the Vienna Circle: Affinities and Divergences
}

\author{
Nikolay Milkov
}

My collaboration with the Vienna Circle does not mean an agreement with the number of naiveties which it conveyed to us from Vienna (and to which I also count Schlick's Ethics), but that this union is a result of the compulsion of the isolation in which the school philosophy put the exact philosophers. ${ }^{1}$

\subsection{Asymmetry in the History of the Vienna and Berlin Scientific Philosophy}

The Vienna Circle and the Berlin Group were allied schools of scientific philosophy that together strove against what they understood to be a philosophical traditionalism that lost touch with the real world. The term "logical empiricism," as this scientific philosophy came to be called in the last years, ${ }^{2}$ can be seen as the philosophy of the two Germanic capitals, Berlin and Vienna. Both cities were at the forefront of the modernity and, prior to the Second World War, leading centers of science and research. The cultural milieu in which the new scientifically oriented philosophy was nurtured departed perceptibly from what had long been the traditional seedbed of Germanophone philosophy, namely the small university town such as a Marburg or a Heidelberg, a Graz or a Jena.

\footnotetext{
${ }^{1}$ Reichenbach's letter to Heinrich Scholz from 13.10.1931 [HR 013-31-06].

${ }^{2}$ For criticism of this term see the last paragraphs of Sect. 1.8.

N. Milkov $(\bowtie)$

Department of Philosophy, University of Paderborn, Paderborn, Germany

e-mail: nikolay.milkov@upb.de
} 
The present chapter's objective is to correct the historical record, which till now has failed to present the rise and evolution of logical empiricism with due regard to its full complexity. The usual understanding is that the Vienna Circle dominated the scientific philosophy of the twentieth century's third and fourth decades. As we shall see, however, this view reflects what, at best, is only a superficial historical reading of scientific philosophy during that period. More exacting analysis yields a far different picture - one in which the Berlin Group, following a research program all its own, figures as an equal partner with the Vienna Circle in promulgating, around 1930, the scientific philosophy in the German-speaking world. Hans Reichenbach, for one, frequently underscored the Berlin Group's autonomy as a principal player in the emergence of logical empiricism. What's more, he emphasized the lead role that the Group in fact took in originally formulating the doctrine, citing as his personal contribution to this effort his introduction of the method of "logical analysis of science" in his book The Theory of Relativity and Apriori Knowledge (Reichenbach 1920, 74 ff.). Reichenbach also called attention to the circumstance that "die Erkenntnis ... was founded in Berlin [not in Vienna] and edited from there.",3

The asymmetry that marks the currently accepted view of scientific philosophy in the German speaking countries around 1930 is in large part owing to the absence of any monograph on the history of the Berlin Group. That of the Vienna Circle, on the other hand, is preserved in a number of widely read texts, some authored by wellestablished scholars like Viktor Kraft, Oswald Hanfling, Rudolf Haller, Friedrich Stadler and Thomas Uebel. It is true that by the late 1980s publications began to appear that covered the history of the Berlin scientific philosophy as well as the particular projects of Reichenbach and his Group (Leitko 1987). And the wave of enthusiasm that German reunification aroused had an impact on scholarship which included newly issued collections of papers on the history of the Berlin Group, ${ }^{4}$ including letters and documents - most notably among them a document describing the sessions of the Society for Empiric/Scientific Philosophy. ${ }^{5}$ As a whole, however, these publications amount to little more than preliminary work on the history of the Berlin Group. Even collectively, they do not give us a comprehensive picture of the ideas it introduced, debated, and developed. Little wonder, then, that they have failed to correct the mainstream view, in which for many years now Reichenbach has often been cast as a "logical positivist and Vienna Circle insider" (Moran 2008, 180).

\footnotetext{
${ }^{3}$ Reichenbach's letter to Ernst von Aster, June 3, 1935 [HR-013-39-34]. Indeed, the manuscripts submitted to Erkenntnis were to be sent to Berlin, not to Vienna. This is reflected in the fact that on the cover of the first four volumes of the journal, Reichenbach's name was printed in bigger characters than the name of the official co-editor Carnap.

${ }^{4}$ We mean here above all Danneberg et al. (1994), Haller and Stadler (1993), Hentschel (1991), and Poser und Dirks (1998).

${ }^{5}$ Cf. Danneberg and Schernus (1994). We shall speak about this double naming of the Society a little bit later.
} 
As we shall see, however, not only did Reichenbach differentiate himself from the logical positivists, he regarded himself as their "friendly opponent." 6

\subsection{Why the Asymmetry?}

To be sure, no conspiracy was responsible for the disparity in prominence between the Vienna Circle and the Berlin Group, and the conspicuous absence of the latter from the received historical record. This situation devolved largely from one theoretical and three external factors that actually have little to do with strengths or weaknesses of the Berlin Group's philosophical program. ${ }^{7}$

The theoretical factor that made the Vienna Circle's activities the more visible was Ludwig Wittgenstein's philosophy of language, a doctrine that owed a great deal to Gottlob Frege's work on the topic. Wittgenstein's influence proved catalytic in the Circle's effort to articulate a set of related topics and problems which made possible its "planned co-operative project [die planmässige Kollektivarbeit]" (Neurath 1932, 208). This initiative came to life in a long series of discussions on themes such as the nature of truth, protocol sentences, and physicalism.

The Berlin Group's project was perceptibly different from that of the Vienna Circle. The Berliners' plan was to explore philosophical problems with scientists and mathematicians in their specific disciplines, its modus operandi being, as Reichenbach declared, "to gather together a group of men working with empiricist methods and fully conscious of their intellectual responsibility" (Reichenbach 1936a, 159). The objective of the Vienna Circle, by contrast, was to advance specific theories: for example, to reach consensus on the question of "protocol sentences." Invariably the discussions in Vienna were passionate, the participants being committed to the imperative of struggling to hammer out a common theory. It is true that they never reached such a common theory. Their energetic debates, however, part of which went to press, called attention to themselves in ways not seen in the Berlin Group.

Reichenbach had in mind just these key differences with his Vienna colleagues when he remarked that

in the line of their more concrete working-program, which demanded analysis of specific problems in science, [the Berliners] avoided all theoretical maxims like those set up by the Vienna school and embarked upon detailed work in logistics, physics, biology, and psychology. (Reichenbach 1936a, 144)

\footnotetext{
${ }^{6}$ In order to understand what the predicate "friendly" meant in German philosophy around 1930, we must recall how hostile the relation between, what later were called, continental and analytic philosophers (for example, between Carnap and Heidegger) was.

${ }^{7}$ On this point, we agree with Peter Simons that "the way philosophical disputes get decided and the way subsequent history is written depend little on the dialectical strength, adequacy or sophistication of the position posed" (Simons 1997, 442).
} 
We further consider the theoretical differences between the Vienna Circle and the Berlin Group (in Sect. 1.7, below). As for the principal external factors that explain the preponderant public interest in the Vienna Circle, three stand out as of particular importance:

(i) The Vienna Circle became prominent the moment its manifesto appeared in August 1929, which riveted attention as a succès de scandale in the philosophical community and beyond. In brief, the manifesto had a radical, clearly spelled out thesis that shocked the general educated public, namely that traditional philosophy is not false-it is senseless. The Circle's objective was no less than to eliminate metaphysics. Little wonder, then, that within two years after publishing its program the Circle had secured itself a prominent place in the philosophical literature. ${ }^{8}$ A couple of years later, the young Alfred Ayer's book Language, Truth, and Logic (1936) made the ideas of the Vienna Circle attractive to the Anglophone students of philosophy.

It deserves note that the Vienna Circle's prominence was due in no small measure to the rhetorical skills of a charismatic person experienced at courting public opinion: such was Otto Neurath, lead author of the manifesto. Predictably enough, critics emerged to rebuke the Vienna Circle for its resort to rhetoric. No one did that better Wittgenstein, who issued the following challenge in a 1929 letter to Friedrich Waismann: "the Vienna School should not prostitute itself like all Vienna institutions want to do on all occasions ... The Vienna school must not say what it achieves, but show it!" (Mulder 1968, 389). In contrast, the Berlin Group exercised a kind of intellectual modesty.

(ii) Among the accidental factors impacting the progress of a new philosophical movement is the strength of character and individual temperaments of its exponents. Here again, the Berliners were at a disadvantage. Only one of its members, Reichenbach, fully developed his philosophical program. The most distinguished example of those who failed to do so was Kurt Grelling (18861942). In 1908 he discovered what we know today as the "Grelling Paradox." Two years later he wrote a brilliant dissertation under Hilbert and Zermelo on the axioms of arithmetic, as well as an influential treatise on probability. Instead of persisting in his efforts to secure a university position, however, he went to Munich to study economics in $1910 .{ }^{9}$ Back in Göttingen in 1913, Grelling further pursued his studies under Leonard Nelson. ${ }^{10}$ After a break with Nelson in 1922, he removed to Berlin where from the autumn of 1926 he worked under his old acquaintance, Reichenbach. ${ }^{11}$

\footnotetext{
${ }^{8}$ Cf. Kaila (1930), Petzäll (1931), and Bloomberg and Feigl (1931).

${ }^{9}$ Hempel's impression, too, was that Grelling “didn't want to enter a university career. I don't quite understand why" (Hempel 2000, 6; my italics-N. M.).

${ }^{10}$ On Grellings's work with Leonard Nelson, see Sect. 1.4, below.

${ }^{11}$ On the contacts between Grelling and Reichenbach before 1926, see Sect. 1.5.
} 
In his Berlin period, Grelling became what was later known as a "mainstream analytic philosopher," trenchantly critiquing the wide range of major new books and papers in scientific philosophy-most notably Carnap's Aufbau, Reichenbach's The Philosophy of Space and Time, and Dubislav's Die Definition (cf. Grelling 1929, 1930, 1933). He also served as a managing editor of Erkenntnis. But Grelling achieved maturity as an original philosopher only in the last years of his life (after 1938). Stimulated by discussions with Paul Oppenheim during that period, ${ }^{12}$ Grelling produced original ideas in formal ontology (cf. Grelling 1939; Grelling and Oppenheim 1937/1938, 1939). ${ }^{13}$ Tragically, the late flowering of his philosophical talent ended in Auschwitz's ovens on September 18, 1942.

By contrast with Grelling, Walter Dubislav (1895-1937) quickly advanced as an independent author. By 1931 he was Extraordinary Professor at the Technical University in Berlin. The political changes in Germany in 1933, however, marked a break in his career-and in his life: after Hitler came to power, Dubislav published scarcely anything. Apparently, the reason was that Dubislav, who unlike Reichenbach and Grelling was not Jewish but "Aryan," "believed that his connection with it [the journal Erkenntnis; but also with the Society of which he took the helm upon Reichenbach's departure] would be harmful for his career." 14 Sadly, Dubislav was all too prescient on this score.

Decades later, Olaf Helmer remembered Dubislav as "a brilliant logician and teacher" who "began to exhibit what were then considered to be paranoid tendencies, abetted no doubt by the political circumstances of the time" (quoted in Luchins 2000, 238). Consequently, when Reichenbach departed Berlin in the summer of 1933, the young members of the Berlin Group, Hempel and Helmer, did not ask Dubislav but other academics (Wolfgang Köhler and Georg Feigl, respectively) to supervise their dissertations. In 1937, Dubislav committed suicide under tragic circumstances.

(iii) A third "external" factor accounting for the dissimilar fates of the Vienna Circle and the Berlin Group was political. Whereas Hitler came to power in Berlin in January 1933, he did not force Austria into the German Reich (schließ es an) for more than 5 years (in March 1938). This afforded the members of the Vienna Circle more of an opportunity than the Berliners in the face of fascist tyranny to regroup and maneuver for a more or less organized exodus.

\footnotetext{
${ }^{12}$ On Paul Oppenheim cf. Sect. 1.5 (iii), n. 38, and Chaps. 12 and 13.

${ }^{13} \mathrm{Cf}$. Chaps. 10 and 11 . Typically, this turn was preceded by an argument with Reichenbach. Cf. Sect. 1.6, (b).

${ }^{14} \mathrm{~A}$ letter of Felix Meiner to Reichenbach from 5.12.33 [HR 013-24-33].
} 


\subsection{The Berlin Group and the Society for Empirical/Scientific Philosophy}

Some scholars (cf. Hoffmann 1994, 2007) represent the Berlin Group and the Society for Empirical/Scientific Philosophy as one and the same entity. Others, whose position is shared here, insist that these were two clearly different communities (cf. Danneberg and Schernus 1994, 394; Gerner 1997, 85 f.). That the Group was not identical with the Society explains why some Group members, Kurt Grelling, for one, did not lecture at the Society. On the other hand, leading members of the Board of the Society, like Richard von Mises, were clearly not a part of the Berlin Group.

The difference between the Berlin Group and the Society was somewhat analogous to that between the Vienna Circle and the Ernst Mach Association. Each school evidently regarded its respective society or association as a forum for communicating with the educated public at large (Neurath 1929, 305).

One clear difference with the Vienna Circle was that the Berlin Group was not formally organized. Whereas the Berlin Group was an informal gathering of thinkers which originated with a seminar that Reichenbach had led at the University of Berlin starting the autumn of 1926 (a couple of years later Reichenbach was conducting joint seminars with Dubislav ${ }^{15}$ ), the Vienna Circle convened regularly for meetings chronicled in detailed minutes.

First documents recording the birth of the Berlin Group date from the beginning of 1928. ${ }^{16}$ That it soon achieved a high degree of organizational integrity is inferable from the fact that when in September 1929 Reichenbach declined an offer to become an (Extraordinary) Professor at the German University of Prague, one of the reasons he gave was his membership in a Berlin discussion group. ${ }^{17}$

It is largely thanks to Reichenbach that we have a published record of Berlin Group activities. Worth noting in this connection is that all his work that supplies data on the Group appeared after he left Germany in 1933. Two years later in Paris it was "in the name of the Berlin Group" that Reichenbach welcomed the Congrès international de philosophie scientifique (Reichenbach 1936b, 16). A programmatic paper of his that appeared in 1936, titled "Logistic Empiricism in Germany and the Present State of its Problems," provides the most detailed description extant of the Berlin Group (and it serves as a primary source in much of what follows below). As late as 1953, Reichenbach did not forget to mention the Group in the preface to the German edition of The Rise of Scientific Philosophy (Reichenbach 1953, 9).

Carl Hempel remembered the Berlin Group as "a small closed discussion group of scholars [that] imposed no membership restrictions. Reichenbach, Dubislav, and Grelling were the leading figures" (Hempel 1991, 6). Besides Reichenbach,

\footnotetext{
${ }^{15}$ Cf. Danneberg and Schernus (1994, 396, n. 26).

${ }^{16} \mathrm{Cf}$. Reichenbach's letter to Heinrich Scholtz from 05.01.1928 [015-41-15].

${ }^{17}$ Cf. Gerner $(1997,106)$.
} 
Grelling, Dubislav and Alexander Herzberg, ${ }^{18}$ at different periods the Group included Fritz London, Wolfgang Köhler and Kurt Lewin. Among the younger members were Carl Hempel, Olaf Helmer, Valentin Bargmann and Martin Strauss.

Important for understanding the character of the Berlin Group is the tradition to organize and take part in formal discussion groups that had its roots for the Berliners in Leonard Nelson's Göttingen-based Neo-Frisian Group to which most of the older generation of Berliners belonged. ${ }^{19}$ Such discussion groups generated a remarkable collaborative spirit, as the following account attests:

Reichenbach gave one the sense that one was a member of a team. His seminar was an open forum; he didn't sit there and have the answer, but he said, 'What can we do about this?' He had an idea, but he was open to counterproposals and also to criticism. So it was exhilarating. One had a sense of participating in an attack on an important problem. (Hempel 2000, 6 f.)

Typically, with his arrival in Istanbul, Reichenbach launched "a colloquium held by a small circle of scholars speaking German" (Hempel 1991, 10). But he deplored the circumstance that the group was "only a weak substitute for the circle in Berlin" (ibid.). A fact most material to the present discussion is that Reichenbach needed such a circle.

If anything, the same is still more true of Kurt Grelling. In conjunction with two of his seminars and a colloquium that he privately conducted, Grelling organized a new "Berlin Circle" in 1936, which included Franz Graf Hoensbroech, Leopold Löwenheim and Jürgen von Kempski on its rolls (Peckhaus 1994, 63). More than this: in the very teeth of Nazi persecution Grelling organized a colloquium in 1941in Gurs internment camp in South (Vichy) France (on the French-Spanish border). He led the colloquium until 1942, when, even as Oppenheim and Hempel and others were attempting through diplomatic channels to rescue him with an appointment at the New School for Social Research in New York, he was transported to Auschwitz and murdered (ibid., $66 \mathrm{ff}$ ).

Among other things, the foregoing facts make it clear that the Berlin Group was limited neither geographically to Berlin, nor temporally to the period of 1926-33.

Unlike the Berlin Group, the Society for Empirical/Scientific Philosophy, with which members of the Group developed formative ties, was formally organized if not officially registered in court records of the time. It had a president, board, manager and a scrupulously compiled list of members. It defined its activity through lectures and discussions, hosting from 10 to 20 talks per year. The Society usually met on Tuesdays at the famous Charité hospital. Contrary to common belief, the "Empirical Philosophy" in the Society's name did not refer to the variety of scientific philosophy to which the Berlin Group subscribed. The Ernst-Machian Josef Petzoldt, who founded the Society in February 1927, set it up as the Berlin chapter (the "Berlin Local Group") of the "International Society for Empirical Philosophy." The latter was organized in 1925 in Frankfurt am Main in support

\footnotetext{
${ }^{18}$ On Alexander Herzberg see Schernus (1994).

${ }^{19}$ See Sect. 1.4, below.
} 
of the journal Annalen der Philosophie which already had something of a scientific orientation. Initially, it was launched as a Journal in support of the "as if" philosophy of the Neo-Kantian Hans Vaihinger.

During the Society's first year and a half, Reichenbach remained skeptical about its viability, formally becoming a member only in October 1928. Ironically enough, it was Neurath who prompted Reichenbach to become a full member of the Berlin Society and eventually to change its agenda. Neurath's idea was for a reformed Berlin Society that would be a counterpart—not necessarily a satelite organization—of the Ernst Mach Association. ${ }^{20}$

It so happened that at just this time Petzoldt fell ill and resigned in May 1929. Reichenbach, Dubislav and Herzberg were thereupon elected to the Board of the Society: Reichenbach as a President (Vorsitzender), Dubislav as a Manager (Geschäftsführer). On June 30, 1929 Reichenbach wrote to Carnap: "Recently Dubislav and I were integrated into the Board, where we, together with Herzberg, have the real power" [HR 013-39-34]. The Berlin Group's interest in the Society's work grew during the ensuing 2 months, particularly after the Vienna Circle published its manifesto in August. The next couple of years saw Reichenbach and his colleagues transform the structure of the Society, such that by the end of 1931 the "Society for Empirical Philosophy" was rechristened the "Society for Scientific Philosophy." 21

The Society's membership largely represented the scientific elite of Berlin but also of other scientific centers in Germany. Most were seasoned researchers and respected authorities in their fields, many of them holding lead positions at prestigious academic departments and institutes (Hoffmann 1994, 27). Boasting more resident Nobel Prize winners than any other city on the planet, ${ }^{22}$ the Berlin of that period was a world-class centre of scientific research; and the lineup of lecturers hosted by the Society included no less than three Nobel Prize laureates: Max von Laue, Otto Meyerhoff, and Wilhelm Oswald.

Besides providing renowned conventional scientists the opportunity to disseminate their findings to some of their most distinguished colleagues in other scientific disciplines, the Society was a forum for innovative scientists, like the founder of Gestalt psychology Wolfgang Köhler and the brain researcher Oskar Vogt. Not surprisingly, the Society attracted talented up-and-coming interdisciplinary scholarscientists, such as the biologist and systems theorist Ludwig von Bertalanffy from Vienna. As a means of furthering their own original research programs, these scientists sought out precisely the sort of stimulus to innovative thinking that the Society's philosophically keyed interdisciplinary discussions fostered..$^{23}$

Finally, the Society also exerted influence on the wider cultural environment. Its list of members included leading avant-garde intellectuals such as Bertolt Brecht

\footnotetext{
${ }^{20} \mathrm{Cf}$. Reichenbach's letter to Philipp Frank of 1.05.29 [HR 014-06-31].

${ }^{21}$ Cf. Sect. 1.7, (ii), below.

${ }^{22}$ Cf. Leitko (1998, 154).

${ }^{23}$ Cf. Sect. 1.7, (ii), below.
} 
and Robert Musil, ${ }^{24}$ both of whom often attended its sessions. The leftist social philosopher Karl Korsch, a close friend of Dubislav, was twice the Society's featured lecturer.

\subsection{Intellectual Background}

Besides divergent programs and organizational formats, the differences between the Vienna Circle and the Berlin Group can be also reconstructed in terms of their intellectual pedigrees. While the leading figures of the Vienna Circle emphasized its mission in continuing the work of Ernst Mach, Reichenbach resisted associating his Group with Mach's name. He categorically repudiated Mach's practice of dismissing for positivistic reasons fruitful scientific theories-the atomic theory in physics, for example. Reichenbach saw the philosophy of the Berlin Group as historically related to "Kantianism and Friesianism," with particular intellectual debts to Ernst Cassirer and Leonard Nelson (Neurath 1930, 312). ${ }^{25}$

This suggests the Berlin Group's deep roots in German philosophy of the "big nineteenth century" (1789-1914) which featured two major currents of thought. The more widely known of the two, especially outside Germany, was German Idealism. Less well known was the nineteenth-century German scientific philosophy associated with Fechner, Fries, Herbart, Lotze, Hertz, and Helmholtz. ${ }^{26}$ Even the Neo-Kantians, whom the Logical Empiricists sought so forcefully to disprove, were mainly interested in the epistemology of science - in both its natural and humanistic forms (i.e., in both the Naturwissenschaften and the Geisteswissenschaften). What distinguished the scientifically oriented German philosophers of the fin de siècle from the later Logical Empiricists was that the former persisted in the belief that philosophy has its own discrete realm of knowledge. The most influential proponents of this old dogma were Cassirer, the Marburg Neo-Kantian, and Nelson, the Göttingen Neo-Friesian. ${ }^{27}$

Leonard Nelson (1881-1927) played a particularly significant role in this story. Nelson's professional friendship with David Hilbert and his group in Göttingen marked a new kind of interdisciplinary collaboration between philosophy and

\footnotetext{
${ }^{24}$ The Viennese Musil was 1931-33 in Berlin.

${ }^{25}$ This sentence in Neurath's "Remarks" was written by Reichenbach. Cf. Reichenbach's letter to Otto Neurath of 24.04.1930 [HR 013-41-70].

${ }^{26} \mathrm{How}$ little this period of the German philosophical thought is known today is clear when we glance in the Routledge Philosophy of Science Encyclopedia in which we read: "What is called philosophy of science today has its roots in both the British and the Austrian tradition ... (with Bolzano, Mach, and others)" (Sarkar and Pfeifer 2006, xi).

${ }^{27}$ On the influence of Ernst Cassirer on the Berlin Group see the last paragraph of Sect. 1.7, (ii), as well as Chap. 4. It deserves notice that Nelson and Cassirer were engaged in a heated dispute. In 1906 Nelson published a very negative review of Hermann Cohen's book Logik der reinen Erkenntnis (1902). Cassirer's answer to Nelson was reciprocally antagonistic.
} 
mathematics (Peckhaus 1990). In 1904 Nelson founded the journal Abhandlungen der Fries'sche Schule (n.s.), which by 1937 produced six volumes, with four carefully prepared issues per volume. Notable among the many distinguished papers that first saw print in the journal is Grelling's exposition of the already mentioned paradox named in his honor and four contributions by Paul Bernays.

In 1913 Nelson founded the Jakob Friedrich Fries Society, which met regularly until 1921. This Society's charter, drafted as early as $1908,{ }^{28}$ clearly shows it to be a predecessor of the Society for Empirical/Scientific Philosophy. Like the Berlin Society, the Göttingen Fries Society was an interdisciplinary forum where philosophers, scientists, and mathematicians together mooted various philosophical problems related, most importantly, to the latest results of scientific and mathematical research, presented in their original, technically articulated form—not abridged or simplified in any way.

Thanks mainly to the good offices of David Hilbert and Felix Klein, in 1919 the University of Göttingen appointed Nelson an Extraordinary Professor (Extraordinarius) of "systematic philosophy of the exact sciences." Symbolically enough, Moritz Schlick was the second on the Göttingen short-list. The appointment committee selected Nelson "because at the time he was the author of more influential work and had greater impact on his colleagues than Schlick" (Franke 1991, 136). Unfortunately, Nelson's appointment came on the heels of the Great War and, dashing Hilbert's hopes, he precipitately threw himself into the fight for (far left) political causes, dying exhausted at the age of 45 in 1927.

As we shall see in Sect. 1.5, clear lines of succession extended from the Jakob Friedrich Fries Society to the Berlin Group. Except for 3 years spent in Munich, Kurt Grelling worked together with Nelson in Göttingen from 1905 till 1922. The mathematician and David Hilbert's assistant Paul Bernays, Nelson's close friend, was an active member of the Fries Society and later became affiliated with the Berlin Group. Hilbert himself found the work of the Society for Empirical Philosophy so important that he took care to convince Reichenbach and his colleagues to change the Society's name, which toward the end of 1931 became, as we have noted, the "Society for Scientific Philosophy" (Joergensen 1951, 48). Indeed, this title much more accurately reflected the Society's character. ${ }^{29}$ Interestingly, one of the last papers read before the Society for Scientific Philosophy in 1934 was presented by Grete Hermann, who had been Nelson's academic assistant in the last few years of his professorship. ${ }^{30}$

The historical roots of the Berlin Society for Empirical Philosophy, by contrast with the Berlin Group, go back to 1912 with the founding of the Society for Positivist Philosophy by Joseph Petzoldt in Berlin. Petzoldt's Society briefly

\footnotetext{
${ }^{28}$ Cf. Peckhaus (1990, 152 f).

${ }^{29}$ See Sect. 1.7, (ii), below.

${ }^{30}$ Grete Hermann was also active in earlier sessions of the Society. In one of them she claimed that quantum physics can be easily made to agree with determinism; Werner Heisenberg found this idea very interesting (Danneberg and Schernus 1994, 396-7, n. 26).
} 
published its own journal, Zeitschrift für positivistische Philosophie (1913-1915) and was ultimately absorbed by the Kant Society in 1921, its members forming the "positivist group" within that association (Danneberg and Schernus 1994, 401). Another antecedent of the Berlin Society for Empirical Philosophy was the German Union of Monists, with Ernst Haekel as its poster child. Out of this group came such active members of the Berlin Society as Count Georg von Arco, Max Deri, and Reichenbach's intimate friend Alexander Herzberg, who later became a full member of the Berlin Group. From 1920 till 1931 the Union published the journal Monistische Monatschrifte. ${ }^{31}$

Walter Dubislav, who became a member of the Society in May 1927, played a pivotal mediating role in establishing its affiliation with the Berlin Group. Petzoldt came to befriend Dubislav (Dubislav 1929b) and proved instrumental to the younger man's successful Habilitation in 1928.

\subsection{The "First Berlin Group"}

As already noted, between 1910 and 1913 Kurt Grelling studied political economy in Munich. Reichenbach might well have first gotten to know Grelling while he himself was in Munich in 1912 and 1913. As Flavia Padovani reports, "they both were very actively engaged in the Freistudentenschaft. [ . . So] they could have met at one of the Free Student Body meetings in Munich" (Padovani 2008, 37).

Be that as it may, while in Göttingen in the spring of 1914, Reichenbach befriended members of Leonard Nelson's group of neo-Friesians, the central figure of which was Grelling. Later Reichenbach reported that already in 1914 Grelling criticized in discussions his attempt "to base probability claim on a claim of certainty" (Eberhardt and Glymour 2008, 23). Between April and September 1914 Dubislav was also at the University of Göttingen, renting the house at 59 Nikolausberger Weg, which was next door to that of Leonard Nelson who lived at 61. It is an established fact that during his stay in Göttingen in 1914, Dubislav developed a serious interest in the philosophy of Fries and Nelson, an abiding interest that later became clearly evident in Dubislav's Die Fries'sche Lehre von der Begründung (1926a), Über den sogenannten analytischen und synthetischen Urteile (1926b), and Zur Methodenlehre des Kritizismus (1929a).

It is thus more than likely that the three future members of the Berlin Group discussed philosophy as early as the hot summer of 1914. Ten years later Reichenbach recollected in a letter to Erich Regener: In 1914 "I was befriended by some members of the Nelson Circle who like myself were interested in problems of natural philosophy" [HR 016-16-03]. This friendship of the young Reichenbach gained prominence at the vegetarian restaurant in Göttingen on one of the first days of the general mobilization in August 1914, where he got involved in a brawl with

\footnotetext{
${ }^{31}$ On the history of the Monist Group cf. Herzberg (1928).
} 
a nationalist group of students who were harassing foreign nationals. This incident led to talk that Reichenbach was a "Nelsonian." Indeed, the vegetarian restaurant in Göttingen was the local hangout of the neo-Friesians, Nelson being perhaps the first philosopher ever rigorously to defend animal rights with philosophical arguments.

Around 1925, when Reichenbach began seeking a professorship, the persistent rumors about his affiliation with Nelson became a problem for him. To be sure, Nelson's Group was (rightly enough) seen in Weimar Germany as politically far left and as such inappropriate to associate with if one were a prospective servant of the state (as the position of state university professor was, and still is, in Germany). This explains why Reichenbach tried to play down his connection with the neoFriesians. In the previously cited 1925 letter to Erich Regener, Reichenbach insisted that he was never a member of the Nelson circle.

There was, however, also another reason why Reichenbach kept his distance from Leonard Nelson: this was a dispute with Nelson that occurred in the summer of 1914 again. ${ }^{32}$ Interestingly enough, the disagreement did not concern the philosophy of science but rather the philosophy of education, about which both men nurtured passionately held positions at the time. While Nelson insisted that all "progressive people" in Germany ought to adopt Hermann Lietz's educational reforms, Reichenbach argued that the "movement of the young" that he championed was much more ambitious than Lietz's program. The theory of education that Reichenbach himself embraced originated with Gustav Wyneken, a sharp critic of Lietz. ${ }^{33}$

Worth noting here is also that Reichenbach, who earned his $\mathrm{PhD}$ in 1915, had Paul Hensel as his dissertation director in Erlangen. Hensel, it turns out, was close to Nelson (who called him "honorary uncle" [Nennonkel]). The neo-Friesians were evidently instrumental in establishing the relation between Reichenbach and Hensel. Given that Reichenbach never studied in Erlangen, his move to select Hensel as his dissertation director would remain rather a puzzle if not for his contact with the neo-Friesians. ${ }^{34}$

Hensel came to play an important role in the pioneering Conference on Exact Philosophy held at Erlangen in March of $1923 .{ }^{35}$ The Conference convened in the villa of the newly established Philosophical Academy, which had been founded by Hensel's former doctoral student Rolf Hoffmann. ${ }^{36}$ In 1925 the Academy launched

\footnotetext{
${ }^{32} \mathrm{Cf}$. Reichenbach (1914). The character of this dispute is to be perhaps better understood with reference to the fact that, in general, Reichenbach had problems with persons that purposivelly strived to influence the public opinion. Typical examples are Otto Neurath and Carl Popper. Leonard Nelson was at least as resolute to exercise influence on society as these two. (I am indebted for this remark to Andreas Kamlah.)

${ }^{33}$ Additional information on the conflict between Hermann Lietz and Gustav Wyneken is to be found in Chap. 7.

${ }^{34}$ Flavia Padovani, for example, deplores: "The reason why Reichenbach finally veered off to Hensel is not clear" (Padovani 2008, 39).

${ }^{35}$ Cf. Carnap (1936, 14).

${ }^{36}$ Cf. Thiel (1993).
} 
the journal Symposion. Although only a single volume ever appeared (in four Issues, the fourth published in 1927), Reichenbach, Schlick and Kurt Lewin contributed important articles. In 1928, the successor to the Academy's publishing house, der Weltkreis-Verlag, issued Carnap's Aufbau.

We can trace both the subject and content of Reichenbach's dissertation to the influence of Ernst von Aster, under whom Reichenbach studied at the University of Munich in 1912 and 1913-later Reichenbach repeatedly said that von Aster was the person he was most indebted to in philosophy. While Reichenbach was still in Munich, von Aster published his Prinzipien der Erkenntnislehre (von Aster 1913). It contains a section (Chapter V, $\S 5,290-9$ ) on probability in which von Aster refers to two works only: Carl Stumpf's paper "On the Concept of Mathematical Probability" (1892) and Kurt Grelling's 1910 paper "Philosophical Foundations of the Calculation of Probability." Grelling's piece was mainly a review paper that defended three ideas: (i) objective ("ontological") interpretation of probability against Carl Stumpf's subjectivism; (ii) discrimination between mathematical and philosophical probability introduced by Jacob Friedrich Fries (in his System of Logic, 1811); (iii) the coupling of probability with induction. It deserves notice that Reichenbach followed (i) and (iii) till the end of his days. ${ }^{37,38}$

The positions substantiated in the present section discredit the so called NeurathHaller thesis. The latter contends that the Vienna Circle was a product of the "Vienna liberal enlightenment", by which Otto Neurath and Rudolf Haller referred to Austrian philosophers who putatively had notable affinities with British empiricism and distrusted the obscure German Idealism. By contrast, the German philosophers of the time, or so argued Neurath and Haller, followed above all "Kant and the Kantians, together with Fichte, Hegel and Schelling" (Neurath 1936, 687)understood, of course, as enemies of science and experience. ${ }^{39}$ It is on the strength of this claim that Neurath and Haller sought to explain why we can regard the philosophical events in Austria as "a chapter of an intellectual development in Europe, which had no success in Germany" (ibid., 676).

This assessment is mistaken. First of all, as we have seen, nineteenth-century German philosophy was also scientifically oriented. Second, the Vienna Circle's influence in Vienna itself was rather limited. The majority of the professional philosophers in the Austrian capital around 1930 were idealists (Stadler 1991). Finally, the Berlin Group's history as we have reviewed it in the present chapter makes it clear that the German scientific philosophy was also developed in the Weimar Republic.

\footnotetext{
${ }^{37}$ In his Dissertation Reichenbach also discussed Ernst Friedrich Apelt's Theory of Induction (1854), which appears on Reichenbach's bibliography. Apelt was student and friend of Fries. In the draft of the dissertation, Reichenbach refers as well to Fries' Essay in a Critique of the Principles of Calculus of Probability (1842).

${ }^{38} \mathrm{Cf}$. Eberhardt and Glymour (2008, $\left.15 \mathrm{ff}\right)$.

${ }^{39}$ Today, this claim is controversial: cf. Friedman and Nordmann (2006).
} 
New studies in the history of philosophy of science adduce further evidence against the Neurath-Haller Thesis. Above all, they reveal that the Neo-Kantians as well as Husserl exerted a formative influence on the early Carnap (Friedman 1999; Mayer 1991). Reichenbach also started out as a Neo-Kantian, counting Ernst Cassirer and Alois Riehl among his teachers. What's more, Kant's philosophy itself was clearly scientific in orientation (Friedman 1992). Indeed, Kant is now recognized as having originated a universe of ideas that can be seen as sponsoring both of idealism and of scientific philosophy. In other words, a philosopher could be Kantian and at the same time orient his thinking by appeal to science and mathematics_-precisely what the Neurath-Haller Thesis denies.

\subsection{Realms of Joint Work}

Unfortunately, it is difficult to reconstruct the joint work of the members of the Berlin Group proper (1926-1933). The original sources are scant and there is practically no secondary literature on the Group's collaborative activities. What we can discern, however, is that the Berliners concentrated their efforts in three areas: logic, epistemology, and ethics.

(a) Logic. The collaboration of Reichenbach with Grelling and Dubislav concentrated principally on logic and meta-mathematics. It is evident that Reichenbach deliberately sought collaborators proficient in this realm - they would be of help in his effort to elaborate his own program for "logical (axiomatic) analysis of science." This point is supported by the fact that while in the late 1920s and the early 1930s Berlin hosted other scientifically oriented philosophers, they were not invited to join the Berlin Group. One such thinker was the physicist Paul Hertz, a friend of Reichenbach's from the time of the 1923 Erlangen Workshop.

Collaboration with Dubislav on logic proved especially valuable for Reichenbach. Dubislav's work on definitions ${ }^{40}$ helped Reichenbach to clarify his position on coordinative definitions. A product of this collaboration was Dubislav's 1929 paper Elementarer Nachweis der Widerspruchslosigkeit des Logik-Kalküls (Dubislav 1929c). Appearing in the Crelles Journal, this essay features Dubislav's "quasi truth-tables" $"$; Reichenbach himself pursued work along the same lines. Three years later he employed Dubislav's tables in his paper Wahrscheinlichkeitslogik. ${ }^{42}$ It propped Reichenbach's theory of probability according to which propositions have three predicates: true, false, and their prediction-value or weight (Reichenbach 1938, 28).

(b) Epistemology. In the already mentioned paper Logistic Empiricism in Germany and the Present State of Its Problems (1936a), Reichenbach recalled that

\footnotetext{
${ }^{40}$ Cf. Dubislav (1926c, 1927, 1931).

${ }^{41}$ Cf. Chap. 8.

${ }^{42}$ See also Reichenbach (1947, 127 n).
} 
instead of investigating the principle of verification, or getting entangled in the protocol-sentence debate, the members of the Berlin Group concentrated on probability, which they treated as "theory of propositions about the future." As Reichenbach put it, "there were years of work in Berlin [on this subject], filled with fresh starts and tentative solutions, proposed in ardent discussions, before a definitive theory was reached" (p. 152). Reichenbach here supplies indispensable, firsthand insight into the Group's preoccupations, character, and modus operandi.

We can reconstruct Grelling's position on probability and induction during these years mainly from a text published in Erkenntnis which preserves for us his contribution to the discussion on probability at the 1929 Prague Conference. ${ }^{43}$ This is a programmatic document in which Grelling and Reichenbach attacked Waismann's Wittgensteinian position and that of Carnap as well. Grelling, in particular, insisted that science is possible only when based on the principle of induction - the principle that endows science with its predictive power. However puzzling it might be deemed, the inductive principle is in any case neither empirical nor tautological. "If I were a Friesian," declares Grelling, "I would say that this principle is synthetic a priori" (p. 278). But he was no longer a Friesian. Grelling admitted that he had no solution to this problem; but he was content to have laid it out in its most clear and compelling terms.

In September 1929, Reichenbach shared this problem with Grelling: the only non-empirical point in his epistemology was the principle of induction, or "Hume's problem". After years of joint effort, in 1932/1933 Reichenbach reached a solution to this problem: Induction is based on conjectures, or posits, that are a result of our assessments of the facts. Posits are ultimately a product of our free will and so are purely empirical. Reichenbach called this position radical empiricism, and put it to work in his most influential books: Experience and Prediction (1938), and The Rise of Scientific Philosophy (1951).

Dubislav took up the problem of probability and induction in a lecture before the Society for Empirical Philosophy on December 10, 1929. The text was published almost mot-à-mot in chapter 4.7 ("Induction") of his book Natural Philosophy (Dubislav 1933, 99-114) in which Dubislav concurs with Reichenbach's analysis in virtually every respect.

Grelling started to disagree with Reichenbach's new theory of induction only in 1936 when he adopted Carnap's position that there are two kinds of probability - philosophical and statistical ${ }^{44}$; the difference between them being a matter of convention, of "syntax." 45

(c) Ethics. Dubislav and Reichenbach also shared a joint position in ethics, one that opposed the Vienna Circle's doctrine on the subject. Although both schools

\footnotetext{
43“"Diskussion über Wahrscheinlichkeit”, Erkenntnis 1 (1930): 260-85 (Grelling's contribution is on p. 278).

${ }^{44}$ In fact, this was his position in Grelling (1910). Cf. Sect. 1.5, above.

${ }^{45} \mathrm{Cf}$. Grelling's letter to Reichenbach of 28.01.1936 [HR 013-14-04].
} 
took anti-cognitivist stands in ethics, the Vienna philosophers championed a form of emotivism: they maintained that value judgments are expressions of our emotions. This position distinguished two forms of understanding, knowledge and emotions, the problem with it being that, as a matter of fact, this position was based on a conception of the German (Dilthey's) "life-philosophy" (cf. Gabriel 2004) that the Vienna Circle officially radically opposed.

In contrast, Reichenbach and Dubislav regarded all ethical propositions as implicit commands. ${ }^{46}$ Thus as with scientific propositions, which are posits, the propositions of ethics are, according to Reichenbach and Dubislav, products of the free will. ${ }^{47}$ The two philosophers saw this position as most radically empiricist.

\subsection{Autonomy of the Berlin Group}

The Vienna Circle and the Berlin Group were unquestionably closely related academic communities. While studying at the University of Vienna in the Winter Term 1929/1930, the Berliner Carl Hempel took part in sessions of the Vienna Circle; and Martin Strauss was from 1934 through 1938 Philipp Frank's postdoctoral student in Prague. On the other hand, Carnap and Neurath lectured at the Berlin Society for Empirical/Scientific Philosophy. Richard von Mises, in his turn, served as a bridge between the Berlin Society and the Ernst Mach Association.

At the same time, each of the schools had its own distinctive character. Indeed, as we already have remarked and as we shall see further in the present section, the two groups proceeded on grounds that were clearly divergent from each other-the scientifically oriented philosophy in Vienna took as its points d'appui philosophy of language and philosophical logic, while the Berlin Group's activities centered on logical analysis of the newest scientific discoveries. ${ }^{48}$ This difference in orientation is clear in the two "Introductions" to Erkenntnis, one by Reichenbach and the other by Schlick (Reichenbach 1930; Schlick 1930), which outlined two different programs of scientific philosophy. Understandably, in view of the considerable dissimilarity of their programs, Schlick declined several invitations to lecture before the Berlin Society, while the Vienna Circle never invited Reichenbach to read a paper-this despite several requests on his part to do so $^{49}$ and the fact that the Circle did host other international philosophers and logicians, such as Eino Kaila and Alfred Tarski.

\footnotetext{
${ }^{46}$ Cf. Dubislav (1937), Reichenbach (1947, 344), Reichenbach (1951, 280 ff). Cf. Chap. 7.

${ }^{47}$ Nicholas Rescher, who considers himself one of the successors of the "Berlin Group in America" (Rescher 2005), developed this stance in his The Logic of Commands (1966).

${ }^{48} \mathrm{Cf}$. Sect. (ii), below.

${ }^{49} \mathrm{Cf}$. Reichenbach's letter to Schlick from 2.01.1933 [HR 013-30-13].
} 
Apparently, Vienna and Berlin treated their collaboration as a marriage of convenience. ${ }^{50}$ Ostensibly their shared objective was to show the educated public of the time that together they made a front of scientifically oriented thinkers that opposed the traditional philosophy, with its claim to be an autonomous discipline featuring its own truths. In fact, however, there were considerable differences between Vienna Circle from the Berlin Group. Three in particular are of interest here:

(i) Different Masterminds. As we have previously remarked, while Vienna, in a general sense, took Ernst Mach as its guiding spirit, Berlin was post-Friesian. With respect to active participants in the two groups, Wittgenstein exerted a formative influence upon scientific philosophers in Vienna. Indeed, as early as the academic years 1923 through 1925, the Tractatus was discussed mot-àmot in Schlick's seminars. Starting in 1926, the nucleus of the Vienna Circle systematically studied Wittgenstein's book (Stadler 1997, 227 f.). Crediting the seminal power that Wittgenstein's ideas had in the evolution of Vienna Circle philosophy helps to make comprehensible the Circle's preoccupation with such matters as the discrimination of metaphysics from science, the elimination of metaphysics (that is why they were called "logical positivists") and the principle of verification. These topics were scarcely discussed in Berlin, where Wittgenstein's impact was comparatively limited. ${ }^{51}$

The Berlin Group's philosophical hero was not Wittgenstein but Bertrand Russell. This is evidenced by, among other things, Kurt Grelling's translation into German of four of Russell's books in the 1920s (Milkov 2005). Grelling's translations no doubt aided Reichenbach in mastering Russell's philosophy, something evident in two brief but highly informed and laudatory essays titled, "Bertrand Russell" (Reichenbach 1928b, 1929).

Russell, however, was a complex philosopher whose views were subject to radical shifts and whose thought cut across the interests of both the Vienna Circle and the Berlin Group. On the one side, especially in the teens of the last century, he largely subscribed to Frege's and Wittgenstein's philosophy of language. This bears on Russell's doctrine of the logical construction of the world out of elements of the given (snese-data), by way of the logic of relations; for he developed this line of thought under Wittgenstein's influence (Milkov 2002). On the other side, Russell remained deeply interested in the latest scientific developments and discoveries, specifically with an eye toward subjecting them to philosophical analysis and to assessing their value for philosophy. It was this second, scientifically attuned Russell that most interested the members of the Berlin Group.

\footnotetext{
${ }^{50}$ See the motto to this chapter.

${ }^{51}$ In fact, the only message of Wittgenstein assimilated in Berlin was the thesis that logic is tautological in character.
} 
The Berlin Group had closest contacts with two of the lead figures in the science and the mathematics of the day: Einstein and Hilbert. Of course, these two men also influenced the Vienna Circle, albeit in a somewhat different way. The Circle construed the formative findings of Hilbert and Einstein as, first and foremost, definitive refutations of the idea of apriori truths. The neopositivists held that the sciences proceed on the basis of material that we perceive through our senses. This position was embraced in Berlin as well (in the form of physicalism), in particular after Reichenbach introduced his "radical empiricism" thesis in 1932/1933. Prior to that development, scientific philosophers in Berlin were more interested in specific philosophical aspects of the newest scientific and mathematical theories. This explains, among other things, why at that period Reichenbach, unlike Neurath, did not hesitate to call himself a "philosopher." 52 Indeed, the former's main objective was to cultivate the philosophical insights engendered by the most recent discoveries and theories in science and mathematics.

In the 1920s Reichenbach won wide recognition as the leader of the "defense belt around Einstein". 53 To be sure, some members of the Vienna Circle were penetrating philosophical interpreters of the Theory of Relativity. Schlick in particular, who trained under Max Planck, was the first to propose it an empirical interpretation (Schlick 1918). As we have observed, however, after 1924 he turned to the intensive study of Wittgenstein, which precipitated a dramatic shift in his philosophical interests (Ferrari 2008).

Especially noteworthy here is that between 1926 and 1929, the defining years of the Vienna Circle and the Berlin Group, Reichenbach led deeply probing Group discussions with Einstein, ${ }^{54}$ while Schlick and Carnap (Carnap as from 1927) hosted intensive meetings with Wittgenstein as the star guest. These engagements proved formative for the two groups.

Also highly influential among the members of the Berlin Group was David Hilbert. As we have seen, all three of the leading Berliners-Grelling, Reichenbach and Dubislav—studied under Hilbert in Göttingen (Hilbert was Grelling's Doktorvater). For Hempel, too, "the atmosphere in Göttingen was very, very stimulating. The two terms there influenced [him] very strongly" (Hempel 2000, 5). This was not the case with the three principal figures of the Vienna Circle: Schlick, Neurath, and Carnap. The latter two had never studied in Göttingen, and when Schlick was there as a graduate student in 1904 and 1905 , he was totally preoccupied with experimental work in physics and never sought out Hilbert (Iven 2008, 108 ff.). It can come as no surprise, then, that

\footnotetext{
${ }^{52}$ Moreover, Reichenbach showed willingness for "peaceful debates" with "speculative", or idealistic, philosophers, such like Oskar Becker. See Reichenbach (1931a).

${ }^{53}$ Stölzner $(2001,108)$. Reichenbach's papers in apology of the Theory of Relativity were recently published in Reichenbach (2006).

${ }^{54}$ One piece of evidence is Einstein's review of Reichenbach's Philosophy of Space and Time. Cf. Einstein (1928).
} 
while, for example, Walter Dubislav arduously defended Hilbert's formalism against the logicism of Frege (Dubislav 1930), Carnap was and remained a logicist who considered axiomatic simply an "applied logistic." 55

Hilbert's greatest influence on the Berlin Group flowed from his project to axiomatize the sciences, something clearly related to Reichenbach's program for logical analysis of science. To be more exact, Hilbert claimed that in order to set out the foundations of a given science, we have to "set up a system of axioms which contains an exact and complete description of the relations subsisting between the elementary ideas of that science." 56 Reichenbach's objective in the 1920s was precisely this: to axiomatize the philosophy of space and time and to formulate it in strict logical order. It was realized in three of his books: Reichenbach 1920, 1924 and 1928. In this way he synthesized two lines of influence, that of Hilbert and that of Einstein.

Scarcely anything demonstrates more clearly the different orientations of Vienna and Berlin (under Göttingen influence) than the criticism that Hans Hahn and Philipp Frank leveled at Hilbert's notion of axiomatization as a general theory of science. Taking the lead from Ernst Mach's positivistic postulate for strict demarcation between mathematics and physics, Hahn and Frank argued that the axiomatic method, which strives at "deepening the foundations" of science, is infected with metaphysics (Stölzner 2002). In this, they followed the motto of the Vienna Circle: "In science there are no 'depths': there is surface everywhere" (Neurath 1929).

(ii) The Berlin Program for Logical Analysis of Science. We have already seen indications that the empiricism of the Berlin Group differed substantially from the empiricism that members of the Vienna Circle embraced. At its height, the Circle advanced the neo-positivist shibboleth that "the meaning of every statement of science must be statable by reduction to a statement about the given"-i.e., about sense-data or experiences (ibid., 309). Its guiding positivist theme was roughly speaking an Ernst Machian interpretation of Wittgenstein's Tractatus.

By contrast, the Berlin Group propounded the view that the only sources of knowledge are scientific observations, experiments, and theories-not some apriori judgments, as Kant believed, nor our sense-data. Moreover, it contended that this view "is the very first condition of empiricism" (Reichenbach 1936a, 152). ${ }^{57}$

Apparently, the schools of Vienna and Berlin subscribed to different versions of empiricism. Interestingly enough, Kurt Lewin insisted that instead of "empiricism," the position of Reichenbach should be called "observatism"

\footnotetext{
${ }^{55}$ Cf. Chap. 13. It deserves notice that around 1930, Carnap's interest in Hilbert radically increased (arguably, under Dubislav's and Reichenbach's influence), a development that found expression in his Logical Syntax (1934).

${ }^{56}$ Hilbert (1900, 447). Cf. Peckhaus (2003).

${ }^{57}$ Italics mine-N. M.
} 
(Lewin 1925, 91). More so since the Berlin Group and the Society were interested not only in problems of empirical science but also in those of theoretical physics, theoretical biology, mathematics, and technique-and these are scarcely "empirical."

Reichenbach agreed with Kant that science functions thanks to certain principles and axioms. He maintained, however, that these come and go with every significant scientific discovery. Reichenbach's conclusion was that the task of philosophy is to "logically analyze" the newest scientific theories: it "penetrates the results of the special sciences to philosophical questionformulation" (Anonymous 1930, 72). This it does in order: (i) to distill their axioms and principles; (ii) to explicate the connection of our experience with the conceptual systems of scientific theories. Philosophy realizes these aims, according to Reichenbach, with the help of coordinating definitions that constitute the objects of science.

In this way Reichenbach replaced Kant's apriori judgments with relativised and dynamic constitutive principles that change from theory to theory such that every well-developed theory has its own constitutive principles (Friedman 2005 , 125). Moreover, pace Kant, the principles of different sciences do not on this account diverge radically one from another: they are not different in type. It follows that the task of scientific philosophers is to explore the everchanging fundamental principles that sponsor all of the sciences.

This conclusion played a seminal role in the formation of the Society for Scientific Philosophy. ${ }^{58}$ It makes clear, in particular, why once Reichenbach and his friends acquired control over the "Society for Empirical Philosophy" after June 1929 they renamed it by the end of 1931 into the "Society for Scientific Philosophy."

Plainly the ultimate, if merely adumbrated objective animating the program for logical analysis of science was to compare the principles of different scientific disciplines in order to stimulate the further development and articulation of those principles (Milkov 2011, $151 \mathrm{n}$. 14). Such was the rationale for gathering together scientists of different disciplines. Apparently, the hope was that these interdisciplinary studies would lead to the birth of new disciplines, such as the now-established fields of cybernetics, game theory, and systems theory. The program also sought to foster interdisciplinary influences similar to that which some 20 years later the physicist Erwin Schrödinger exerted on the biologists Francis Crick and Maurice Wilkins, and which lent impetus to the discovery of the structure of DNA. And while in the latter instance the crossdisciplinary interaction and the discoveries did not occur in the setting of the Society for Scientific Philosophy, the principals had connections with it: Schrödinger's assistant, Fritz London, for example, was a quondam member of the Berlin Group; as already mentioned, the Society for Scientific Philosophy hosted Ludwig von Bertalanffy as lecturer three times and members of the

\footnotetext{
${ }^{58}$ Cf. Sect. 1.3, above.
} 
Berlin Group published extended reviews of his writings over the years (see Hempel 1951). Finally, Reichenbach expressed the conviction that his own work in "natural philosophy" anticipated Werner Heisenberg's Principle of Indeterminacy (cf. Reichenbach 1931b, 40 f.) (Cf. Chap. 6).

The Vienna Circle's interdisciplinary program exhibited considerably more of an ideological cast than did that of the Berlin Group. In particular, the Circle sought to demonstrate the unity of science in terms of a system of related concepts, the ultimate aim being to show that the humanities do not follow a method fundamentally different from that of the natural sciences. In this connection it deserves notice that comparing the papers read before the Ernst Mach Association with those presented at the Society for Scientific Philosophy reveals that the Society hosted lecturers which were more in line of the leading science of the time (cf. Danneberg and Schernus 1994, 478-81; Stadler 1997, 379-81).

Reichenbach was convinced that there was an acute need for a logical analysis of science such as his. Scientists prefer, as he noted, to concentrate on discovering new facts and constructing new theories, rather than on making their theories logically_and epistemologically_more coherent: this is the task of scientific philosopher. "Scientific research does not leave a man time enough to do the work of logical analysis," observed Reichenbach, "and ... conversely logical analysis demands a concentration which does not leave time for scientific work" (Reichenbach 1951, 123). The two academic disciplinesscience and scientific philosophy-share the same subject-matter and so both should be harnessed in tandem to pull the "car of knowledge." Reichenbach urged, moreover, that scientific philosophy is as technically sophisticated as the sciences themselves, and that it frequently corrects scientific theories when they are initially framed. The logical analysis of science is thus anything, then, but mere scientific journalism.

Carnap openly criticized Reichenbach on this score, insisting that "the investigation of facts is the task of the natural-scientific, empirical research, the investigation of the language forms is the task of the logical, syntactical analysis" (Carnap 1936, 265). The latter task, asserted Carnap, is the defining project of scientific philosophy.

When speaking of the Berlin Group's work in "logical analysis" one needs to bear in mind that in early analytic philosophy the term was understood in two different senses. On the one hand, for the likes Schlick and Carnap "logical analysis" referred above all to philosophical logic and philosophy of the language of science; on the other, thinkers such as Reichenbach used the term in conjunction with distilling the new principles of science. In fact, "logical analysis," "conceptual analysis," "clarifying of concepts," "conceptual confusion," "logical forms," "analysis of the language of science," and "rational reconstruction" all meant significantly different things for Reichenbach than they did for Schlick and Carnap. When, for example, Reichenbach spoke about the "logical analysis" of science, what he had in mind was closer to what 
we think of as "axiomatic analysis." He first evinced serious interest in logic only after 1928, under the influence of Grelling and Dubislav.

From a historical perspective, logical analysis of science, such as the Berlin Group conceived it, exhibited close methodological affinities with the Marburg Neo-Kantian analysis (principally Ernst Cassirer's analysis) of the structure (the "logic") of science. ${ }^{59}$ Relative to its context in the scientific philosophy of the time, Reichenbach's program, in particular, shares elements of Kurt Lewin's interdisciplinary variant of Cassirer's method (Lewin 1925). ${ }^{60}$ In fact, when Reichenbach initially elaborated his method of the logical analysis of science in his Relativitätstheorie und Erkenntnis apriori, Lewin (1920) was the only published work to which he referred in its support (Reichenbach 1920, n. 20). ${ }^{61}$ From that period forward and till the end of the 1920 s, Reichenbach and Lewin regularly cited each other's work in their publications (Wittmann 1998, 184).

(iii) Social Work. Besides the differences in theory, the Vienna Circle and the Berlin Group pursued divergent social aims. Whereas Neurath's goal was to reorganize the social and economic life of his country (and eventually the world), Reichenbach nurtured the more modest social ambition of elevating the status of science in society and, more particularly, in philosophy. A "great evangelist of science" (van Fraassen 2002, 224), Reichenbach sought among other things to set up professorships throughout Germany in the scientific philosophy of nature. To this end, in 1931 Reichenbach composed a sixtypage petition that he submitted to the Ministry of Science, Art and Education of the Weimar Republic. The cover letter was signed by a host of luminaries, including Einstein and Hilbert. Reichenbach hoped to publish the petition in Erkenntnis, but this plan fell through when his Vienna Circle colleagues objected (Danneberg and Schernus 1994, 404 n. 56).

Roughly at the same time, at the request of Wolfgang Windelband, the Prussian Minister of Science, Art and Education, Moritz Schlick wrote a formal assessment of Reichenbach's achievements as scientific philosopher. Schlick's findings were unequivocal: “I consider [Reichenbach's] main ideas in analysis of causality and probability false. It appears that in this realm a peculiar, inflexible adherence to certain ideas prevents him from reaching the ultimate depth." 62 Ironically enough, Wolfgang Windelband was the son of Wilhelm Windelband, the head of the Southwest Neo-Kantians, whom both the Viennese and Berlin schools of scientific philosophers fiercely opposed.

\footnotetext{
${ }^{59}$ This point is confirmed by the fact that Reichenbach referred to Ernst Cassirer (his professor at the University of Berlin), when he spoke about the historical roots of the Berlin Group in Neurath $(1930,312)$ (cf. n. 25).

${ }^{60} \mathrm{Cf}$. Chaps. 4, 5 and 14.

${ }^{61}$ The 1920 program of Lewin-Reichenbach was most closely followed by Paul Oppenheim (Oppenheim 1926). Cf. Chap. 13.

${ }^{62}$ Moritz Schlick's letter to Wolfgang Wildenband, 15.03.1931.
} 


\subsection{Logical Positivism and the Rise of Logical Empiricism}

The story of the Berlin Group in its relation to the Vienna Circle is of special interest also because of what it brings to light in the history of analytic philosophy in North America. It is well established that the Group exerted a profound influence in the USA through those of its members who, unlike Dubislav and Grelling, managed to immigrate to America after January 1933. Reichenbach and Hempel in particular contributed signally to a radical change of philosophical climate in the United States, as did Olaf Helmer and Paul Oppenheim (Cf. Chap. 14).

Ronald Giere asserts that after Carnap and Reichenbach resettled in North America, they made themselves over from scientific philosophers (wissenschaftliche Philosophen) into philosophers of science as a means of adapting to their new academic milieu:

They realized, quite rightly, that works like the Aufbau and Relativitätstheorie, which were written in the context of a cultural, scientific, and philosophical tradition that did not then exist in North America, would not be much appreciated in the North American context. So they put their efforts into other projects, ones better suited to their new intellectual and cultural environment. (Giere 1996, 337)

Giere's account, here, is unconvincing. In the first place, by referring only to Reichenbach's early Relativitätstheorie (1920) he obscures the fact that in the later and more mature Philosophie der Raum-Zeit Lehre (1928) Reichenbach produced what is in effect the manifesto of the program for scientific philosophy as it is also practiced today. In fact, elements of philosophy of science had been generally in play in Europe since the late 1920s. In large part this was due, as we have noted (see Sect. 1.7, above), to participants of the Berlin Group, for whom the nascent program evolved pretty much along the same lines that would distinguish the philosophy of science as a autonomous sub-discipline in the USA.

In more recent years Wesley Salmon substantiated these points. A student of Reichenbach's at UCLA Berkeley, Salmon repeatedly asserted what Reichenbach had underscored back in the mid-1930s (Reichenbach 1936a, $151 \mathrm{f}$.), namely that while the Vienna Circle advanced a doctrine of logical positivism, one distinguished by the sharply anti-metaphysical stance shared by each of its members, the Berlin Group championed a program of logical empiricism that logically analyzed the latest findings and theories of the sciences and mathematics. Despite real affinities, the Vienna Circle and the Berlin Group were associations whose structure and proceedings reflected different agendas. True enough, it was the Circle's Otto Neurath who in 1931 coined the term "logical empiricism" (Neurath 1931, 297), one which he came to employ regularly. Nonetheless, Reichenbach more accurately captured the history of the Germanophone scientific philosophy when in 1936 he divided it into Vienna logical positivism and Berlin logical empiricism.

Salmon declared that the second movement-the Berlin logical empiricism"completely superseded" the first one: the Viennese logical positivism (Salmon 1999, 333). But what the evidence indicates more specifically is that this development signaled the historical triumph of the Berlin Group's program and 
the concomitant eclipse of the Vienna Circle's positivist agenda in the realm of philosophy of science. Soon, the logical positivism, the doctrine once shared by all the leading members of the Vienna Circle, was abandoned, whereas the program for the logical analysis of science persisted and remains viable even today (Salmon 2001, 233 f.). In this connection, one should bear in mind that leading members of the Vienna Circle abandoned logical positivism prior to the decimation of the Vienna and Berlin groups under the Nazis.

Too many authors today conflate these developments, and simply identify the Vienna Circle philosophy as "logical empiricism." 63 Typically, the move to represent the Circle in this light gets justified along some such lines as the following: "Logical empiricism is really the story of the development of themes articulated within logical positivism. [... It is] the reexamination, modification, and (alternatively) rejection and endorsement of the themes of logical positivism" (Hardcastle 2006, 458, 464).

If the evidence adduced in the preceding discussion has made anything clear, it is that such a reading is a mistake. The two movements formulated and pursued two different, albeit related, programs of scientific philosophy. To ignore this difference is to obscure the historical record.

\subsection{Philosophy of Science versus Analytic Philosophy of Language}

Recently, Nicholas Rescher published an account, somewhat similar to the present one, of the Berlin Group's scientific philosophy and its influence in the United States (cf. Rescher 2005). Rescher traces back to Berlin the philosophy of science developed over the last four decades at the University of Pittsburgh, as well as at other major research universities across the USA-from Berkeley, Bloomington, and Boston, to Minneapolis and Princeton. He numbers among the luminaries in this American extension and development of the Berlin legacy Carl Hempel, Adolf Grünbaum, Wesley Salmon, Baas van Fraassen, Alberto Coffa, Larry Laudan, and John Earman, among others.

Accurate as Rescher's picture may be, it is essential to bear in mind that the program of the Berlin Group did not totally overshadow the legacy of the Vienna Circle in American analytic philosophy. Indeed, W.V. Quine and his followers at Harvard and elsewhere by and large hewed to Circle's project, continually developing and often correcting it. Moreover, Quinean exact philosophy has proven to be more influential than the philosophy of science inspired by Reichenbach and Hempel. ${ }^{64}$

\footnotetext{
${ }^{63}$ Among the authors that are against such conflation are Philipp Kitcher $(2001,148)$, and Peter Godfrey-Smith $(2003,22)$.

${ }^{64}$ This point has become especially prominent during recent decades (cf. Howard 2000, 75 f.).
} 
While Quine himself understood his philosophy to be closely tied to science, in truth, it was not. Being a very general "science," Quine's doctrine differs perceptually from Reichenbach's real (concrete), or "actual" science. More conceptual in nature than scientific are (i) Quine's discussions of the dichotomy between analytic and synthetic propositions; (ii) his criticism of the sense-data theory, of the "radical reductionism" thesis, of the correspondence theory of truth, etc.; (iii) his defense of the ontological commitment of language; (iv) his interest in "what there is" and which are "the ultimate constituents of the Universe." Quine's philosophy of science is more of an analytic philosophy of language, broadly conceived-one that includes analytic ontology and analytic epistemology. While these sub-disciplines probe the methods and conditions of scientific praxis, they do not address recent scientific discoveries and theories and their immediate philosophical importance.

Analytic philosophy of language (or philosophical logic) originated, as we have noted, with Frege. It saw its most significant early development in some of Russell's works from the period of 1903-1919, reaching its pinnacle in Wittgenstein's Tractatus logico-philosophicus and in the work by the Vienna Circle (cf. Sect. 1.7, (i)). It is true that Quine is known to have shown little interest in Wittgenstein's book $^{65}$; but he closely followed the Carnap of 1926-1935 who did draw largely upon Wittgenstein, and ultimately Frege.

This and similar approaches were later named "external philosophy of science." The "external" aspect that marks this current of thought has to do with the fact that it is not developed in terms of any "inspection of the procedures actually followed by scientists" (McMullin 1970, 24). The "internal philosophy of science," by contrast, "relies for its warrant upon a careful ... description of how scientists actually proceed" (ibid., 26). It was this philosophy that Reichenbach and his colleagues initially formulated around 1930.

Hilary Putnam supplies a telling personal record of the experience of jettisoning analytic philosophy of language of science for Reichenbach's logical empiricism in a way that reflects the difference between the two programs:

I did a year of graduate work at Harvard in 1948-1949, where I came under influence of Quine's views on ontology and his scepticism concerning the analytic/synthetic distinction. At that point, I was in a mood that is well known to philosophy teachers today: it seemed to me that the great problems of philosophy had turned out to be pseudoproblems. [...]

Within a few months of my arrival in Los Angeles in the fall of 1949 these philosophical "blahs" had totally vanished. What overcame my "philosophy is over" mood, what made the field come alive for me, made it more exciting and more challenging than I had been able to imagine, was Reichenbach's seminar, and his lecture course on the philosophy of space and time. (Putnam 1991, 61)

Lamentably, for decades philosophers cast a blind eye to the all-important contrasts that differentiated these two philosophical currents. Russell, in particular, had insisted that they were mutually complementary. He discovered the serious disagreements between the two only in his later years (in particular, in his Human

\footnotetext{
${ }^{65}$ In contrast to his friend Burton Dreben and his acolytes at Harvard.
} 
Knowledge, 1948), when he returned to his old ambition to pursue philosophical inquiries into science. Likely enough it was Reichenbach who awoke Russell from his philosophy-of-language slumbers, for the two shared an office when Russell was at the University of California at Berkeley in 1940.

\subsection{Epilogue}

The foregoing sections enable us to recast, in a general way, our picture of the history of analytic philosophy in post-World War II America. During the second half of the twentieth century analytic philosophy in the United States evolved along lines that reflected the contrasting currents of scientific philosophy that took their definitive form in Berlin and Vienna around 1930. Roughly speaking, whereas Carnap and his student Quine, as well as the latter's follower, Donald Davidson, were engaged mainly with problems of analytic philosophy of language, in conjunction with philosophical logic, Reichenbach and his student Hempel (along with Hempel's students Putnam, Grünbaum, Salmon, and their followers van Fraassen and John Earman) devoted themselves, by contrast, to internal philosophy of science and hence pursued the philosophy of science that analyzes the facts of concrete scientific practice. ${ }^{66}$

\section{References}

Anonymous. 1930. Gesellschaft für empirische philosophie: Berlin. Erkenntnis 1: 72-73.

Ayer, Alfred. 1936. Language, truth, and logic. London: Gollancz.

Blumberg, Albert E., and Helmut Feigl. 1931. Logical positivism. A new movement in European philosophy. Journal of Philosophy 28: 281-296.

Carnap, Rudolf. 1936. Von der Erkenntnistheorie zur Wissenschaftslogik. In Wiener Kreis, ed. Michael Stoeltzner and Thomas Uebel, 260-266. Hamburg: Felix Meiner.

Cohen, Hermann. 1902. Logik der reinen Erkenntnis. Berlin: Cassirer.

Danneberg, Lutz, and Schernus Wilhelm. 1994. Die Gesellschaft für wissenschaftliche Philosophie. In Hans Reichenbach und die Berliner Gruppe, ed. Lutz Danneberg et al., 391-481. Braunschweig: Vieweg.

Danneberg, Lutz, et al. (eds.). 1994. Hans Reichenbach und die Berliner Gruppe. Braunschweig: Vieweg.

Dubislav, Walter. 1926a. Die Fries'sche Lehre von der Begründung: Darstellung und Kritik. Dömitz: Mattig.

Dubislav, Walter. 1926b. Über den sogenannten analytischen und synthetischen Urteile. Berlin: Weiss.

Dubislav, Walter. 1926c. Über die definition. Berlin: Weiss.

Dubislav, Walter. 1927. Über die definition, 2nd ed. Berlin: Weiss.

\footnotetext{
${ }^{66}$ Preliminary versions of this Chapter were read at the Universities of Bochum, Graz, Pittsburgh and Vancouver. I am grateful for stimulating discussions.
} 
Dubislav, Walter. 1929a. Zur Methodenlehre des Kritizismus. Langensalza: Beyer \& Söhne.

Dubislav, Walter. 1929b. Joseph Petzoldt in memoriam. Annalen der Philosophie 8: 289-295.

Dubislav, Walter. 1929c. Elementarer Nachweis der Widerspruchslosigkeit des Logik-Kalküls. Journal für die reine und angewandte Mathematik 161: 107-112.

Dubislav, Walter. 1930. Über den sogenannten Gegenstand der Mathematik. Erkenntnis 1: 27-48.

Dubislav, Walter. 1931. Die definition, 3rd ed. Leipzig: Felix Meiner.

Dubislav, Walter. 1933. Naturphilosophie. Berlin: Junker und Dünnhaupt.

Dubislav, Walter. 1937. Zur Unbegründlichkeit der Forderungssätze. Theoria 3: 330-342.

Eberhardt, F., and C. Glymour. 2008. Introduction. In The concept of probability in the mathematical representation of reality, ed. Hans Reichenbach, and trans. Frederick Eberhardt, and Clark Glymour, 1-36. Chicago: Open Court.

Einstein, Albert. 1928. Hans Reichenbach: Philosophie der Raum-Zeit-Lehre. Deutsche Literaturzeitung 1: 19-20.

Ferrari, Massimo. 2008. Moritz Schlick in Wien: Die Wende der Philosophie. In Moritz Schlick: Leben, Werk und Wirkung, ed. Fynn O. Engler and Mathias Iven, 91-113. Berlin: Parerga.

Franke, Holger. 1991. Leonard Nelson. Ammersbek bei Hamburg: Verlag an der Lottbek.

Friedman, Michael. 1992. Kant and the exact sciences. Cambridge: Cambridge University Press.

Friedman, Michael. 1999. Reconsidering logical positivism. Cambridge: Cambridge University Press.

Friedman, Michael. 2005. Ernst Cassirer and contemporary philosophy of science. Angelaki 10: $119-128$.

Friedman, Michael, and Alfred Nordmann (eds.). 2006. The Kantian legacy in nineteenth-century science. Cambridge, MA: MIT Press.

Gabriel, Gottfried. 2004. Introduction: Carnap brought home. In Carnap brought home. The view from Jena, ed. S. Awodey and C. Klein, 3-23. Chicago: Open Court.

Gerner, Karin. 1997. Hans Reichenbach: Sein Leben und Wirken. Osnabrück: Autorenpress.

Giere, Ronald. 1996. From wissenschaftliche philosophie to philosophy of science. Minnesota Studies in the Philosophy of Science 16: 335-354.

Godfrey-Smith, Peter. 2003. Theory and reality: An introduction to the philosophy of science. Chicago: The University of Chicago Press.

Grelling, Kurt. 1910. Die philosophische Grundlagen der Wahrscheinlichkeitsrechnung. Abhandlungen der Fries'schen Schule 3: 439-478.

Grelling, Kurt. 1929. Realism and logic: An investigation in Russell's metaphysics. The Monist 39: 501-520.

Grelling, Kurt. 1930. Die Philosophie der Raum-Zeit-Lehre. Philosophischer Anzeiger 4: 101-128.

Grelling, Kurt. 1933. Bemerkungen zu Dubislav, Die Definition. Erkenntnis 3: 189-200.

Grelling, Kurt. 1939. A logical theory of dependence. In Foundations of gestalt theory, ed. Barry Smith 1988, 217-228. München: Philosophia.

Grelling, Kurt, and Paul Oppenheim. 1937/1938. Der Gestaltbegriff im Lichte der neuen Logik. Erkenntnis 7: 211-225. 357-359.

Grelling, Kurt, and Paul Oppenheim. 1939. Logical analysis of 'Gestalt' as 'functional Whole'. In Foundations of gestalt theory, ed. Barry Smith, 210-216. Philosophia: München.

Haller, Rudolf, and Stadler Friedrich (eds.). 1993. Wien-Berlin-Prag. Der Aufstieg der wissenschaftlichen Philosophie. Wien: Hölder-Pichler-Tempsky.

Hardcastle, Gary. 2006. Logical empiricism. In The philosophy of science: An encyclopedia, ed. Sahotra Sarkar and Jessica Pfeifer, 458-465. London: Routledge.

Hempel, Carl. 1951. General system theory: A new approach to unity of science. Human Biology 23: 313-322.

Hempel, Carl. 1991. Hans Reichenbach remembered. Erkenntnis 35: 5-10.

Hempel, Carl. 2000. Intellectual autobiography-The interview with Richard Nollan. In Science, explanation, and rationality, ed. James H. Fetzer, 3-35. Oxford: Oxford University Press.

Hentschel, Klaus. 1991. Die Korrespondenz Petzold-Reichenbach. Berlin: ERS. 
Herzberg, Lily. 1928. Die philosophischen Hauptströmungen im Monistenbund. Annalen der Philosophie 7: 113-135. 177-199.

Hilbert, David. 1900. Mathematical problems. Bulletin of the American Mathematical Society 8: 437-479.

Hoffmann, D. 1994. Zur Geschichte der Berliner 'Gesellschaft für empirische/wissenschaftliche Philosophie'. In Hans Reichenbach und die Berliner Gruppe, ed. Lutz Danneberg et al., 21-31. Braunschweig: Vieweg.

Hoffmann, D. 2007. The society for empirical/scientific philosophy. In Cambridge companion to logical empiricism, ed. Alan Richardson and Thomas Uebel. Cambridge: Cambridge University Press.

Howard, Don. 2000. Two left turns make a right: On the curious political career of North American philosophy of science at midcentury. Minnesota Studies in the Philosophy of Science 18: 25-93.

Iven, Mathias. 2008. Moritz Schlick. Die frühen Jahre (1881-1907). Berlin: Paregra.

Joergensen, Joergen. 1951. The development of logical empiricism. Chicago: University of Chicago Press.

Kaila, Eino S. 1930. Der logistische neupositivismus. Eine kritische studie. Turku: Annales Universitatis Fennicae Aboensis.

Kitcher, Philipp. 2001. Carl Hempel. In A companion to analytic philosophy, ed. A.P. Martinich and D. Sosa, 148-159. Oxford: Blackwell.

Leitko, Hubert. 1987. Wissenschaft in Berlin. Berlin: Dietz.

Leitko, Hubert. 1998. Wissenschaft in Berlin um 1930. In Hans Reichenbach: Philosophie im Umkreis der Physik, ed. Hans Poser and Ulrich Dirks, 139-155. Berlin: Akademie Verlag.

Lewin, Kurt. 1920. Die verwandtschaftsbegriffe in biologie und physik und die darstellung vollständiger stammbäume. Berlin: Bornträger.

Lewin, Kurt. 1925. Über Idee und Aufgabe der Vergleichenden Wissenschaftstheorie. Symposion 1: 61-93.

Luchins, Abraham S., and Edith H. Luchins. 2000. Kurt Grelling: Steadfast scholar in a time of madness. Gestalt Theory 22: 228-281.

Mayer, Verena. 1991. Die Konstruktion der Erfahrungswelt—Carnap und Husserl. Erkenntnis 35: 287-304.

McMullin, Ernan. 1970. The history and philosophy of science: A taxonomy. Minnesota Studies in the Philosophy of Science 5: 12-67.

Milkov, Nikolay. 2002. The joint philosophical program of Russell and Wittgenstein (MarchNovember 1912) and its downfall. Contributions of the Austrian Wittgenstein Society 10: $60-62$.

Milkov, Nikolay. 2005. Russell studies in Germany today. The Bertrand Russell Society Quarterly 125(6): 35-47.

Milkov, Nikolay. 2011. Anmerkungen des Herausgebers. In Ziele und Wege der heutigen Naturphilosophie: Fünf Aufsätze zur Wissenschaftstheorie, ed. Hans Reichenbach and N. Milkov, 147-158. Hamburg: Felix Meiner.

Moran, Dermot (ed.). 2008. The Routledge companion to twentieth century philosophy. London: Routledge.

Mulder, Henk. 1968. Wissenschaftliche Weltauffassung: Der Wiener Kreis. Journal of the History of Philosophy 6: 386-390.

Neurath, Otto. 1929. The Vienna circle of the scientific conception of the world. In Empiricism and sociology, ed. Marie Neurath and Robert S. Cohen, 301-318. Dordrecht: Reidel.

Neurath, Otto. 1930. Historische Anmerkungen. Erkenntnis 1: 311-314.

Neurath, Otto. 1931. Physikalismus. Scientia 50: 297-303.

Neurath, Otto. 1932. Protocol sentences. In Logical positivism, ed. Alfred J. Ayer, 199-208. New York: Free Press.

Neurath, Otto. 1936. Die Entwicklung des Wiener Kreises und die Zukunft des logischen Empirismus. In ibid., Gesammelte philosophische Schriften, 2 vols., ed. Rudolf Haller et al., 673-702. Wien: Hölder-Pichler-Tempsky. 
Oppenheim, Paul. 1926. Die natürliche Ordnung der Wissenschaften: Grundgesetze der vergleichenden Wissenschaftslehre. Jena: Fischer.

Padovani, Flavia. 2008. Probability and causality in the early works of Hans Reichenbach, Ph.D. dissertation, Geneva: University of Geneva.

Peckhaus, Volker. 1990. Hilbertprogramm und kritische Philosophie: das Göttinger Modell interdisziplinärer Zusammenarbeit zwischen Mathematik und Philosophie. Göttingen: Vandenhoeck \& Ruprecht.

Peckhaus, Volker. 1994. Von Nelson zu Reichenbach: Kurt Grelling in Göttingen und Berlin. In Hans Reichenbach und die Berliner Gruppe, ed. Lutz Danneberg et al., 53-86. Braunschweig: Vieweg.

Peckhaus, Volker. 2003. The pragmatism of Hilbert's programme. Synthese 137: 141-156.

Petzäll, Åke. 1931. Logistischer Positivismus: Versuch einer Darstellung und Würdigung der philosophischen Grundanschauungen des sog. Wiener Kreises der wissenschaftlichen Weltauffassung. Göteborgs högskolas årsskrift 37: 3. 36 pages.

Poser, Hans, and Ulrich Dirks (eds.). 1998. Hans Reichenbach: Philosophie im Umkreis der Physik. Berlin: Akademie Verlag.

Putnam, Hilary. 1991. Reichenbach's Metaphysical picture. Erkenntnis 35: 61-75.

Reichenbach, Hans. 1914. Zum Lietzschen Vortragsabend. Göttinger Akademische Wochenschau 10:5 (12.06.), 38.

Reichenbach, Hans. 1920. The theory of relativity and a priori knowledge. Trans. Maria Reichenbach. Berkeley: University of California Press.

Reichenbach, Hans. 1928a. Philosophie der Raum-Zeit Lehre. Berlin: de Gruyter.

Reichenbach, Hans. 1928b. [Russell:] An early appreciation. In Bertrand Russell: Philosopher of the century, ed. Ralph Schoenman, 129-133. London: Allen \& Unwin.

Reichenbach, Hans. 1929. Bertrand Russell. In Obelisk Almanach, 82-92. Berlin and Munich: Drei-Masken Verlag.

Reichenbach, Hans. 1930. Zur Einführung. Erkenntnis 1: 1-3.

Reichenbach, Hans. 1931a. Zum Anschaulichkeitsproblem der Geometrie. Erkenntnis 2: 61-72.

Reichenbach, Hans. 1931b. Ziele und Wege der heutigen Naturphilosophie. Leipzig: Felix Meiner.

Reichenbach, Hans. 1936a. Logical empiricism in Germany and the present state of its problems. The Journal of Philosophy 33: 141-160.

Reichenbach, Hans. 1936b. Ansprache bei der Begrüßung der Pariser Kongresses. In Actes de congrès international de philosophie scientifique. Paris 1035, Tome I: Philosophie scientifique et empirisme logique, 16-18. Paris: Hermann.

Reichenbach, Hans. 1938. Experience and prediction. Chicago: University of Chicago Press.

Reichenbach, Hans. 1947. Elements of symbolic logic. New York: The Free Press.

Reichenbach, Hans. 1951. The rise of scientific philosophy. Berkeley: University of California Press.

Reichenbach, Hans. 1953. Der Aufstieg der wissenschaftichen Philosophie. Trans. Maria Reichenbach. Berlin: Herbig.

Reichenbach, Hans. 2006. Defending Einstein: Hans Reichenbach's writings on space, time, and motion, ed. Steven Gimbel and Anke Walz. Cambridge: Cambridge University Press.

Rescher, Nicholas. 1966. The logic of commands. London: Routledge.

Rescher, Nicholas. 2005. The Berlin school of logical empiricism and its legacy. In Studies in 20th century philosophy, ed. Nicholas Rescher, 119-148. Ontos: Frankfurt.

Salmon, Wesley. 1999. The spirit of logical empiricism: Carl G. Hempel's role in twentieth-century philosophy of science. Philosophy of Science 66: 333-350.

Salmon, Wesley. 2001. Logical empiricism. In A companion to the philosophy of science, ed. W.H. Newton-Smith, 233-251. Oxford: Blackwell.

Sarkar, Sahotra, and Pfeifer Jessica. 2006. The philosophy of science: An introduction. In The philosophy of science: An encyclopedia, ed. Sahotra Sarkar and Pfeifer Jessica, xi-xxvi. London: Routledge.

Sarkar, Sahotra, and Jessica Pfeifer (eds.). 2006. The philosophy of science: An encyclopedia. London: Routledge. 
Schernus, Wilhelm. 1994. Alexander herzberg: Psychologie, medizin und wissenschaftliche philosophie. In Hans Reichenbach und die Berliner Gruppe, ed. Lutz Danneberg et al., 3351. Braunschweig: Vieweg.

Schlick, Moritz. 1918. Allgemeine Erkenntnislehre. Berlin: Springer.

Schlick, Moritz. 1930. Die Wende der Philosophie. Erkenntnis 1: 4-11.

Simons, Peter. 1997. Review of Kush, Psychologism. The British Journal for the Philosophy of Science 48: 439-443.

Stadler, Friedrich. 1991. Aspects of the social background and position of the Vienna circle at the University of Vienna. In Rediscovering the forgotten Vienna circle, ed. Thomas Uebel, 51-77. Dordrecht: Kluwer.

Stadler, Friedrich. 1997. Studien zum Wiener Kreis. Frankfurt: Suhrkamp.

Stölzner, Michael. 2001. Die Kausalitätsdebatte in den Naturwissenschaften. Zu einem Milieuproblem in Formans These. In Wissenschaft: Transformationen im Verhältnis von Wissenschaft und Alltag, ed. H. Franz, 85-128. Bielefeld: Institut für Wissenschafts- und Technikforschung.

Stölzner, Michael. 2002. How metaphysical is 'deepening the foundations'?—hahn and frank on Hilbert's axiomatic method. Vienna Circle Institute Yearbook 9: 245-262.

Stumpf, Carl. 1892. Über den Begriff der mathematischen Wahrscheinlichkeit. Sitzungsberichte der philosophisch-philologischen und historischen Classe der Königlich Bayerischen Akademie der Wissenschaften 20: 37-120.

Thiel, Christian. 1993. Carnap und die wissenschaftliche Philosophie auf der Erlanger Tagung 1923. In Wien-Berlin-Prag Der Aufstieg der wissenschaftlichen Philosophie, ed. Rudolf Haller and Stadler Friedrich, 175-188. Wien: Hölder-Pichler-Tempsky.

van Fraassen, Bas. 2002. The empirical stance. New Haven: Yale University Press.

von Aster, Ernst. 1913. Prinzipien der Erkenntnislehre. München: Quelle \& Meyer.

Wittmann, Simone. 1998. Das Frühwerk Kurt Lewins. Frankfurt: Peter Lang. 